\title{
Real-time PCR detection of quarantine plant pathogenic bacteria in potato tubers and olive plants
}

\author{
Milan Ivanović, Nemanja Kuzmanović, Nevena \\ Zlatković
}

\begin{abstract}
This chapter focuses on molecular detection of quarantine plant pathogenic bacteria associated with potato and olive plants. A real-time PCR for detection of two bacteria of potato in Europe: Ralstonia solanacearum race 3 and Clavibacter michiganensis subsp. sepedonicus, is described. This method allows the simultaneous detection of both species in a single PCR reaction with an internal control from potato. Described protocol is sensitive and specific and can be used in large scale screening tests. Quarantine pest Xylella fastidiosa is recently detected in Europe for the first time. Considering the importance of early detection, procedure for real-time PCR detection of Xylella fastidiosa in olive plant tissue is described.
\end{abstract}

\section{Simultaneous detection of Ralstonia solanacearum race 3 and Clavibacter michiganensis subsp. sepedonicus in potato tubers by a multiplex real-time PCR assay}

How to cite this book chapter:

Ivanović, M., Kuzmanović, N. and Zlatković, N. 2019. Real-time PCR detection of quarantine plant pathogenic bacteria in potato tubers and olive plants. In: Vucelić Radović, B., Lazić, D. and Nikšić, M. (eds.) Application of Molecular Methods and Raman Microscopy/Spectroscopy in Agricultural Sciences and Food Technology, Pp. 83-95. London: Ubiquity Press. DOI: https://doi.org/10.5334/bbj.f. License: CC-BY 4.0 


\section{Introduction}

Ralstonia solanacearum (Smith) Yabuuchi et al. race 3 (Rs) and Clavibacter michiganensis (Smith) Davis et al. subsp. sepedonicus (Spieckermann et Kotthoff) Davis et al., (Cms) are the causal agents of brown-rot (Figure 1) and ring-rot (Figure 2) of potato, respectively. These diseases represent a serious threat to potato (Solanum tuberosum) production in temperate climates. Both bacteria are listed as A2 pests in the EPPO region and as zero-tolerance quarantine organisms in the European Union. These bacteria remain latent for a long time in asymptomatic potato tubers which are one of the main factors for the disease's dissemination. The existing phytosanitary regulations rely on the availability of pathogen-free seed tubers.

\section{Materials, Methods and Notes}

Since the protocols involve detection of quarantine organisms and include the use of viable cultures of Rs andCms, it is necessary to perform the procedures under suitable quarantined conditions with adequate waste disposal facilities and under the conditions of appropriate licenses as issued by the official plant quarantine authorities.

\subsection{Sample preparation - potato tubers}

Note:

- The standard sample size is 200 tubers per test. Larger numbers of tubers in the sample will lead to inhibition or difficult interpretation of the results. However, the procedure can be conveniently applied for samples with less than 200 tubers where fewer tubers are available.

- Detection methods described below are based on testing of samples of 200 tubers.

- Optional pre-treatment in advance to sample preparation: wash the tubers. Use appropriate disinfectants (chlorine compounds when PCR-test is to be used in order to remove eventual pathogen DNA) and detergents between each sample. Air-dry the tubers.

- This washing procedure is particularly useful (but not required) for samples with excess soil and if a PCR-test or direct isolation procedure is to be performed.

2.1.1. Remove with a clean and disinfected scalpel or vegetable knife the skin at the heel end of each tuber so that the vascular tissue becomes visible. Carefully cut out a small core of vascular tissue at the heel end and keep the amount of non-vascular tissue to a minimum. 


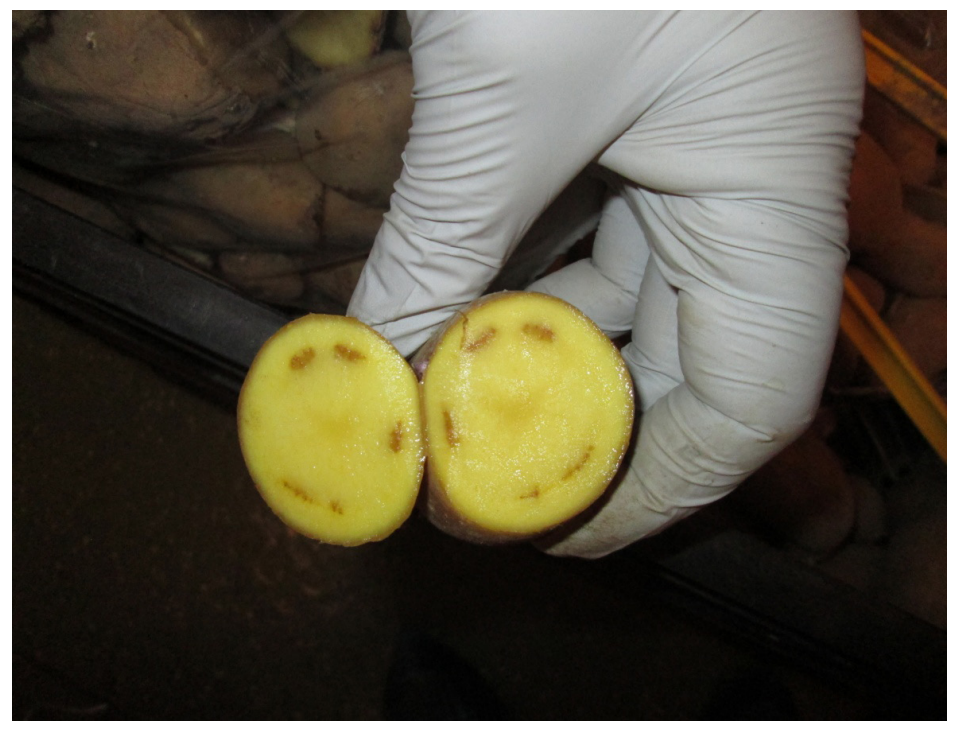

Figure 1: Symptoms of brown rot on stored potato tubers caused by bacteria Ralstonia solanacearum. Note the brown staining of the vascular ring. (Foto: M. Ivanović).

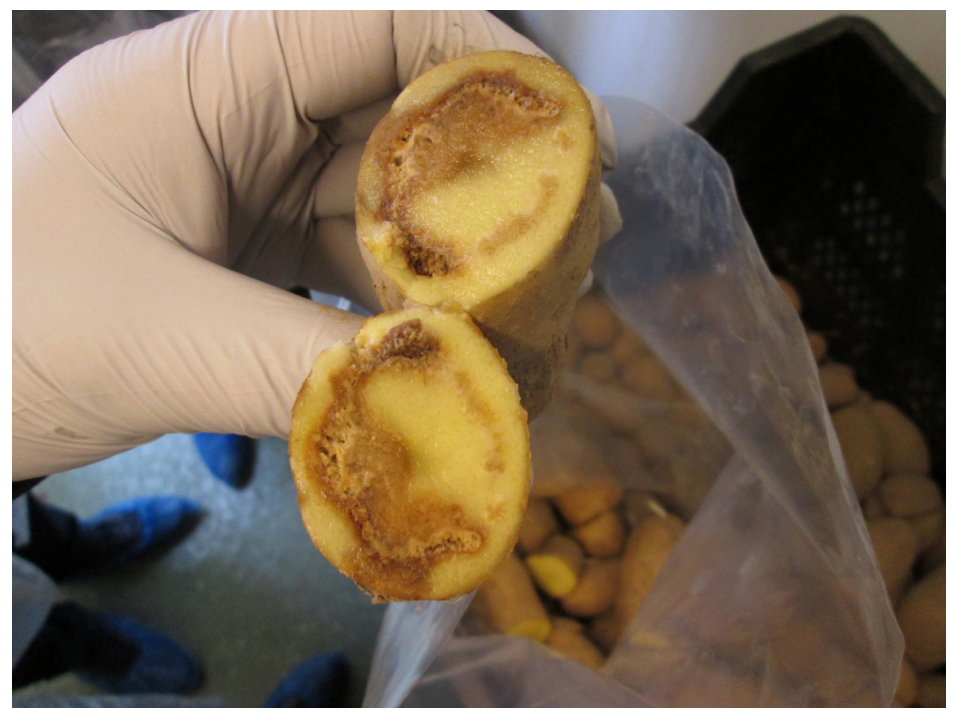

Figure 2: Breakdown and hollowing of stored potato tuber with ring rot, caused by bacteria Clavibacter michiganensis. subsp. sepedonicus (Photo: M. Ivanović). 
Note: If during removal of the heel end core suspect symptoms of ring rot are observed, the tuber should be visually inspected after cutting near the heel end. Any cut tuber with suspected symptoms should be suberised at room temperature for two days and stored under quarantine (at 4 to $10^{\circ} \mathrm{C}$ ) until all tests have been completed.

2.1.2. Collect the heel end cores in unused disposable containers which can be closed and/or sealed (in case containers are reused they should be thoroughly cleaned and disinfected using chlorine compounds). Preferably, the heel end cores should be processed immediately. If this is not possible, store them in the container, without addition of buffer, refrigerated for not longer than 72 hours or for not longer than 24 hours at room temperature. Drying and suberisation of cores and growth of saprophytes during storage may hinder detection of the brown rot and ring rot bacterium.

2.1.3. Process the heel end cores by one of the following procedures: either,

(a) cover the cores with sufficient volume (approximately $40 \mathrm{ml}$ ) of extraction buffer (see recipe below) and agitate on a rotary shaker (50 to $100 \mathrm{rpm}$ ) for four hours below $24^{\circ} \mathrm{C}$ or for 16 to 24 hours refrigerated; or

(b) homogenize the cores with sufficient volume (approximately 40 $\mathrm{ml}$ ) of extraction buffer, either in a blender (e.g. Waring or Ultra Thurax) or by crushing in a sealed disposable maceration bag (e.g. Stomacher or Bioreba strong gauge polythene, $150 \mathrm{~mm} \times$ $250 \mathrm{~mm}$; radiation sterilized) using a rubber mallet or suitable grinding apparatus (e.g. Homex, Bioreba).

Note:

- The risk of cross-contamination of samples is high when samples are homogenized using a blender. Take precautions to avoid aerosol generation or spillage during the extraction process. Ensure that freshly sterilized blender blades and vessels are used for each sample. If the PCR test is to be used, avoid carry-over of DNA on containers or grinding apparatus. Crushing in disposable bags and use of disposable tubes is recommended where PCR is to be used.

- Recipe for extraction buffer (50 mM phosphate buffer): $\mathrm{Na}_{2} \mathrm{HPO}_{4}$ (anhydrous), $4.26 \mathrm{~g}$; $\mathrm{KH}_{2} \mathrm{PO}_{4}, 2.72 \mathrm{~g}$; distilled water, $1 \mathrm{~L}$. Dissolve ingredients, adjust $\mathrm{pH}$ to 7.0 and sterilize by autoclaving at $121^{\circ} \mathrm{C}$ for $15 \mathrm{~min}$.

2.1.4. Decant the supernatant. If excessively cloudy, clarify either by slow speed centrifugation (at not more than $180 \mathrm{~g}$ for 10 minutes at a temperature between 4 to $10^{\circ} \mathrm{C}$ ) or by vacuum filtration (40 to $100 \mu \mathrm{m}$ ), washing the filter with additional $(10 \mathrm{ml})$ extraction buffer. 
2.1.5. Concentrate the bacterial fraction by centrifugation at $7000 \mathrm{~g}$ for 15 minutes (or $10000 \mathrm{~g}$ for 10 minutes) at a temperature between 4 to $10^{\circ} \mathrm{C}$ and discard the supernatant without disturbing the pellet.

2.1.6. Resuspend the pellet in $1,5 \mathrm{ml}$ pellet buffer (see recipe below). Use $500 \mu \mathrm{l}$ to test for Rs, $500 \mu \mathrm{l}$ for Cms, and $500 \mu \mathrm{l}$ for reference purposes. Add sterile glycerol to final concentration of 10 to $25 \%(\mathrm{v} / \mathrm{v})$ to the $500 \mu \mathrm{l}$ of the reference aliquot and to the remaining test aliquot, vortex and store at -16 to $-24^{\circ} \mathrm{C}$ (weeks) or at -68 to $-86^{\circ} \mathrm{C}$ (months). Preserve the test aliquots at 4 to $10^{\circ} \mathrm{C}$ during testing. Repeated freezing and thawing is not advisable. If transport of the extract is required, ensure delivery in a cool box within 24 to $48 \mathrm{~h}$.

Note:

- Recipe for pellet buffer (10 mM phosphate buffer): $\mathrm{Na}_{2} \mathrm{HPO}_{4} \bullet 12 \mathrm{H}_{2} \mathrm{O}, 2.7 \mathrm{~g}$; $\mathrm{NaH}_{2} \mathrm{PO}_{4} \cdot 2 \mathrm{H}_{2} \mathrm{O}, 0.4 \mathrm{~g}$; distilled water, $1 \mathrm{~L}$. Dissolve ingredients, adjust $\mathrm{pH}$ to 7.2 and sterilize by autoclaving at $121^{\circ} \mathrm{C}$ for $15 \mathrm{~min}$.

- It is imperative that all Rs and Cms positive controls, and samples are treated separately to avoid contamination.

\subsection{DNA extraction (method according to Pastrik 2000)}

1.1.1. Pipette $220 \mu \mathrm{l}$ of lysis buffer $(100 \mathrm{mM} \mathrm{NaCl}, 10 \mathrm{mM}$ Tris- $\mathrm{HCl}$ [pH 8.0], $1 \mathrm{mM}$ EDTA [pH 8.0]) into a $1.5 \mathrm{ml}$ Eppendorf tube.

1.1.2. Add $100 \mu \mathrm{l}$ sample extract and place in a heating block or water bath at $95^{\circ} \mathrm{C}$ for $10 \mathrm{~min}$.

1.1.3. Put tube on ice for $5 \mathrm{~min}$.

1.1.4. Add $80 \mu \mathrm{l}$ Lysozyme stock solution (50 mg Lysozyme per $\mathrm{ml}$ in $10 \mathrm{mM}$ Tris $\mathrm{HCl}, \mathrm{pH} 8,0)$ and incubate at $37^{\circ} \mathrm{C}$ for $30 \mathrm{~min}$.

1.1.5. Add $220 \mu \mathrm{l}$ of Easy $\mathrm{DNA}^{\oplus}$ solution A (Invitrogen), mix well by vortexing and incubate at $65^{\circ} \mathrm{C}$ for $30 \mathrm{~min}$.

1.1.6. Add $100 \mu \mathrm{l}$ of Easy $\mathrm{DNA}^{\circledast}$ solution B (Invitrogen), vortex vigorously until the precipitate runs freely in the tube and the sample is uniformly viscous.

1.1.7. Add $500 \mu \mathrm{l}$ of chloroform and vortex until the viscosity decreases and the mixture is homogeneous.

1.1.8. Centrifuge at $15000 \mathrm{~g}$ for $20 \mathrm{~min}$ at $4^{\circ} \mathrm{C}$ to separate phases and form the interphase.

1.1.9. Transfer the upper phase into a fresh Eppendorf tube.

1.1.10. Add $1 \mathrm{ml}$ of $100 \%$ ethanol $\left(-20^{\circ} \mathrm{C}\right)$ vortex briefly and incubate on ice for $10 \mathrm{~min}$.

1.1.11. Centrifuge at $15000 \mathrm{~g}$ for $20 \mathrm{~min}$ at $4^{\circ} \mathrm{C}$ and remove ethanol from pellet. 
1.1.12. Add $500 \mu \mathrm{l} 80 \%$ ethanol $\left(-20^{\circ} \mathrm{C}\right)$ and mix by inverting the tube.

1.1.13. Centrifuge at $15000 \mathrm{~g}$ for $10 \mathrm{~min}$ at $4^{\circ} \mathrm{C}$, save the pellet and remove ethanol.

1.1.14. Allow the pellet to dry in air or in a DNA speed vac.

1.1.15. Resuspend the pellet in $100 \mu \mathrm{l}$ sterile UPW and leave at room temperature for at least 20 minutes.

1.1.16. Store at $-20^{\circ} \mathrm{C}$ until required for PCR.

1.1.17. Spin down any white precipitate by centrifugation and use $5 \mu$ l of the supernatant containing DNA for the PCR.

Note:

- It is also recommended to prepare one decimal dilution of sample DNA extract (1:10 in sterile distilled water) for PCR analysis.

- Other DNA extraction methods, e.g. Qiagen DNeasy Plant Kit, could be applied providing that they are proven to be equally as effective in purifying DNA from control samples containing $10^{3}$ to $10^{4}$ pathogen cells per $\mathrm{ml}$.

\subsection{Real-time PCR assay (method according to Massart et al. 2014)}

This multiplex real-time PCR assay allows simultaneous detection of Rs and Cms in potato tubers. For both bacteria, the primers and probes (Table 1) were selected in the rRNA gene intergenic spacer sequences. Additionally, the reliability of this molecular diagnostic test has been improved by the simultaneous amplification of an internal control, corresponding to a potato gene co-extracted from the sample. For the internal control, primers and probes (Table 1) were designed based on chloroplastic ATP synthase beta-subunit from Solanum tuberosum. The Minor Groove Binder (MGB) probes were supplied by Applied Biosystem with a 5 covalently attached reporter dye (FAM, VIC or NED), a nonfluorescent quencher and MGB moiety at the 3 ' end. The composition of reaction mix and thermal cycling conditions are given in Tables 2 and 3.

The proper negative and positive controls are essential for eliminating falsenegative or false-positive results. In this regard, the following negative controls should be included in the real-time PCR test:

- DNA extracted from sample extract that was previously tested negative for Rs and Cms. Sample extracts should be as free as possible from soil. It could therefore, in certain cases, be advisable to prepare extracts from washed potatoes.

- Buffer controls used for extracting the bacterium and the DNA from the sample,

- Incorporate a negative control sample containing only PCR reaction mix and add the same source of nuclease-free water as used in the PCR mix in place of sample. 


\begin{tabular}{|l|l|l|}
\hline \multicolumn{1}{|c|}{${\text { Primer or } \text { probe }^{\mathbf{a}}}^{\text {Sequence }\left(\mathbf{5}^{\prime} \text { - } \mathbf{3} \text { ') }\right.}$} & \multicolumn{1}{c|}{ Dye } \\
\hline MultiRaso-F & CGCGGAGCATTGATGAGAT & \\
\hline MultiRaso-R & TCGTAATACTGGTTGATACAATCACAAC & \\
\hline MultiRaso-P & CTCGCAAAAACGC & VIC \\
\hline MultiClav-F & TGGTTTCTTGTCGGACCCTTT & \\
\hline MultiClav-R & CGTCCACTGTGTAGTTCTCAATATACG & \\
\hline MultiClav-P & CGTCGTCCCTTGAGTGG & FAM \\
\hline MultiPot-F & GGTTTCGTAATGTTCCTCACCAA & \\
\hline MultiPot-R & AAAGGTATTTATCCAGCAGTAGATCCTT & \\
\hline MultiPot-P & CATGGTTGACGTTGAAT & NED \\
\hline
\end{tabular}

Table 1: Primers and probes for quantitative real-time PCR.

${ }^{a} \mathrm{~F}$, forward; $\mathrm{R}$, reverse; $\mathrm{P}$, probe

\begin{tabular}{|l|l|}
\hline \multicolumn{1}{|c|}{ Reagent } & \multicolumn{1}{c|}{ Volume } \\
\hline Qiagen mix & $12.5 \mu \mathrm{l}$ \\
\hline Molecular grade water & $0.75 \mu \mathrm{l}$ \\
\hline $10 \mu \mathrm{M}$ Forward MultiPot-F Primer & $0.75 \mu \mathrm{l}$ \\
\hline $10 \mu \mathrm{M}$ Reverse MultiPot-R Primer & $0.75 \mu \mathrm{l}$ \\
\hline $10 \mu \mathrm{M}$ TaqMan MultiPot-P Probe & $1.25 \mu \mathrm{l}$ \\
\hline $10 \mu \mathrm{M}$ Forward MultiRaso-F Primer & $0.75 \mu \mathrm{l}$ \\
\hline $10 \mu \mathrm{M}$ Reverse MultiRaso-R Primer & $0.75 \mu \mathrm{l}$ \\
\hline $10 \mu \mathrm{M}$ TaqMan MultiRaso-P Probe & $0.5 \mu \mathrm{l}$ \\
\hline $10 \mu \mathrm{M}$ Forward MultiClav-F Primer & $0.75 \mu \mathrm{l}$ \\
\hline $10 \mu \mathrm{M}$ Reverse MultiClav-R Primer & $0.75 \mu \mathrm{l}$ \\
\hline $10 \mu \mathrm{M}$ TaqMan MultClav-P Probe & $0.5 \mu \mathrm{l}$ \\
\hline Template DNA & $5 \mu \mathrm{l}$ \\
\hline Total & $\mathbf{2 5} \mu \mathrm{l}$ \\
\hline
\end{tabular}

Table 2: Reaction mix for quantitative real-time PCR.

\begin{tabular}{|l|l|}
\hline $95^{\circ} \mathrm{C} 15 \mathrm{~min}$ & 1 cycle \\
\hline $95^{\circ} \mathrm{C} 20 \mathrm{sec}$ & 40 cycles \\
\hline $60^{\circ} \mathrm{C} 60 \mathrm{sec}$ & \\
\hline
\end{tabular}

Table 3: Real-time PCR conditions. 
In addition, the following positive controls should be also included:

- DNA extracted from sample extract that was previously tested negative for Rs and Cms spiked withsuspensions of Rs and Cms(several dilutions)

- DNA extracted from suspension of $10^{6}$ cells per $\mathrm{ml}$ of Rsand Cms in water from a virulent reference strain (e.g. NCPPB $4156=$ PD $2762=$ CFBP 3857 for Rs; NCPPB 2140 or NCPPB 4053 for Cms).

- If possible use also DNA extracted from positive control samples in the PCR test.

To avoid potential contamination prepare positive controls in a separate environment from samples to be tested.

\section{Acknowledgements}

This work was funded by EU Commission project AREA, no. 316004. We would like to thank Dutch General Inspection Service and NAK Institute in Emmeloord, especially Miriam Kooman and Jaap Janse for arranging our visit, Robert Vreeburg and Robert Bollema for laboratory support.

\section{References}

Massart, S., Nagy, C., \& Jijakli, M. H. (2014). Development of the simultaneous detection of Ralstonia solanacearum race 3 and Clavibacter michiganensis subsp. sepedonicus in potato tubers by a multiplex real-time PCR assay. European Journal of Plant Pathology, 138(1), 29-37. DOI: https://doi. org/10.1007/s10658-013-0294-4

Pastrik, K. H. (2000). Detection of Clavibacter michiganensis subsp. sepedonicus in potato tubers by multiplex PCR with coamplification of host DNA. European Journal of Plant Pathology, 106(2), 155-165. DOI: https://doi. org/10.1023/A:1008736017029

\section{Real-Time PCR detection of Xylella fastidiosa subsp. pauca (CoDiRo strain) from olive plants}

\section{Introduction}

The olive quick decline syndrome (OQDS) is a disease that appeared suddenly a few years ago in the province of Lecce (Italy). In 2013, it has been found that the most relevant factor for this disease is a quarantine pathogen Xylella fastidiosa. This was the first confirmed record in the European Union. In addition, 
almond, oleander, cherry and several other perennial ornamentals have been reported as hosts (Cariddi et al. 2014, EPPO 2016). Isolation and culturing of the bacterium on media are fundamental in phytobacteriology, but considering that some Xylella subspecies are very slow-growth, molecular and serological techniques showed as more suitable methods for screening a large number of samples. The purpose of this manuscript is to describe procedure for real-time PCR detection of $X$. fastidiosa in plant tissue.

\section{Materials, Methods and Notes}

Since the protocols involve detection of a quarantine organisms and include the use of viable cultures of $X$. fastidiosa, it is necessary to perform the procedures under suitable quarantined conditions with adequate waste disposal facilities and under the conditions of appropriate licenses as issued by the official plant quarantine authorities.

\subsection{Collecting samples}

During the training, we collected mostly symptomatic or asymptomatic olive plant material for $X$. fastidiosa isolation. Typical symptoms for OQDS are the presence of leaf scorch (Figure 1) and scattered desiccation of twigs and small branches. In the early stages of the infection, symptoms prevail on the upper part of the canopy. Later, these symptoms become increasingly severe and progress into the rest of the crown, which becomes blighted.

\subsection{Sample preparation}

Extraction of $X$. fastidiosa DNA from culture and plant tissue for molecular analyses has been achieved by both standard commercial column kits and

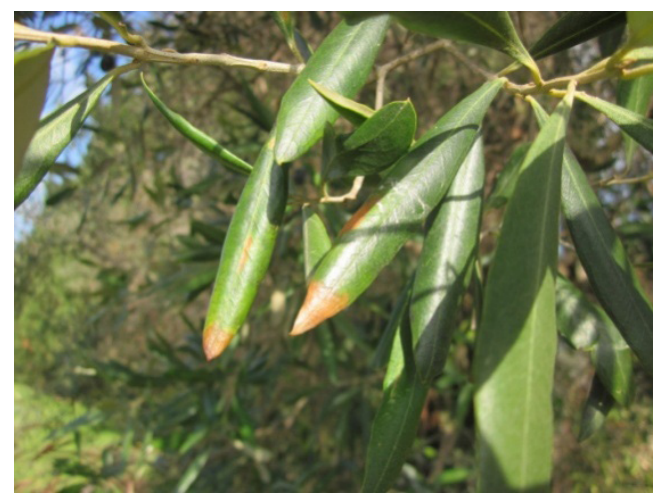

Figure 1: First symptoms of OQDS on olive leaves (Photo: N. Zlatković ). 
by basic CTAB buffer. Basal leaf portion and peduncles excised from mature leaves in total weight between $0,5-0,8 \mathrm{~g}$ are used for DNA extraction. Selected leaves should be representative of the whole sample. Symptomatic leaves have priority.

\subsection{CTAB-based total nucleic acid extraction from plant tissue}

2.3.1. Weigh out $0,5-0,8 \mathrm{~g}$ of fresh small pieces of midribs and petioles $(1 / 4$ if lyophilized), transfer the tissue into the extraction bags and add $2 \mathrm{ml}$ of CTAB. Crush with a hammer and homogenize.

2.3.2. In each extraction bag add $3 \mathrm{ml}$ of CTAB.

2.3.3. Transfer $1 \mathrm{ml}$ of sap into a $2 \mathrm{ml}$ microcentrifuge tube.

2.3.4. Heat samples at $65^{\circ} \mathrm{C}$ for 30 minutes.

2.3.5. Centrifuge samples at $10,000 \mathrm{rpm}$ for 5 minutes and transfer $1 \mathrm{ml}$ to a new $2 \mathrm{ml}$ microcentrifuge tube, being careful not to transfer any of the plant tissue debris. Add 1ml of Chloroform: Isoamyl Alcohol 24:1 and mix well by shaking or vortex.

2.3.6. Centrifuge sample at $13,000 \mathrm{rpm}$ for 10 minutes. Transfer $750 \mathrm{ml}$ to a $1.5 \mathrm{ml}$ microcentrifuge tube and add $450 \mu \mathrm{l}$ (approximately $0.6 \mathrm{vol}$ ume of cold 2-Propanol. Mix by inverting 2 times. Incubate at $4^{\circ} \mathrm{C}$ or $-20^{\circ} \mathrm{C}$ for 20 minutes.

2.3.7. Centrifuge the samples at $13.000 \mathrm{rpm}$ for 20 minutes and decant the supernatant.

2.3.8. Wash pellet with $1 \mathrm{ml}$ of $70 \%$ ethanol.

2.3.9. Centrifuge sample at $13,000 \mathrm{rpm}$ for 10 minutes and decant $70 \%$ ethanol.

2.3.10. Air-dry the samples or use the vacuum.

2.3.11. Re-suspend the pellet in $100 \mu \mathrm{l}$ of TE or RNAse- and DNase-free water.

2.3.12. Extracts of total nucleic acid can be stored at $4^{\circ} \mathrm{C}$ for immediate use or at $2.3 .13 .20^{\circ} \mathrm{C}$ for use in the future.

2.3.14. Determine the concentration at the spectrophotometer (Nanodrop 1000 or similar). Read the absorption (A) at $260 \mathrm{~nm}$ and at $280 \mathrm{~nm}$. Optimal A260/280 ratio should be close to 2 for high quality nucleic acid.

2.3.15. Adjust the concentration to $50-100 \mathrm{ng} / \mu \mathrm{l}$, and use $2 \mu \mathrm{l}$ (in a final volume of $20-25 \mu \mathrm{l}$ ) to set up the conventional and real time PCR reactions.

Note: Recipe for CTAB buffer: 2\% CTAB (Hexadecyl trimethyl-ammonium bromide), autoclaved $0.1 \mathrm{M}$ Tris $\mathrm{HCl} \mathrm{pH} 8$, autoclaved 20mM EDTA, autoclaved 1.4M NaCl, 1\% PVP-40.

\subsection{DNA extraction using commercial kit}

DNeasy Plant Mini Kit, Cat. No. 69104 - Qiagen, Valencia, CA 
2.4.1. Weigh out $200 \mathrm{mg}$ fresh tissue (1/4 if lyophilized) and homogenize with mortar and pestle in liquid nitrogen and transfer powered tissue into $2 \mathrm{ml}$ microcentrifuge tubes. Remaining tissues can be stored at $-20^{\circ} \mathrm{C}$ for future use.

2.4.2. Add $800 \mu \mathrm{l}$ of the Qiagen DNeasy Plant Mini extraction kit AP1 buffer and $8 \mu \mathrm{l}$ of RNase A stock solution $(100 \mathrm{mg} / \mathrm{ml})$ into a sample tube.

2.4.3. Incubate cellular lysate at $65^{\circ} \mathrm{C}$ for $10 \mathrm{~min}$.

2.4.4. Add $260 \mu \mathrm{l}$ of Buffer AP2 to the lysate, vortex briefly and incubate on ice for $5 \mathrm{~min}$.

2.4.5. Centrifuge at $20,000 \times \mathrm{g}(14,000 \mathrm{rpm})$ for $10 \mathrm{~min}$.

2.4.6. Pipet lysate into a QIAshredder Mini Spin Column (lilac colored col$\mathrm{umn}$ ) in a $2 \mathrm{ml}$ collection tube and centrifuge for $2 \mathrm{~min}$ at 20,000 $\mathrm{x}$ $\mathrm{g}(14,000 \mathrm{rpm})$, then, discard the column (typically about $500 \mu \mathrm{l}$ of lysate can be recovered).

2.4.7. Measure the volume and add 1.5 volumes of Buffer AP3/E to the lysate and mix by pipetting.

2.4.8. Transfer $650 \mu \mathrm{l}$ of the mixture including any precipitate to the DNeasy Mini Spin Column sitting in a $2 \mathrm{ml}$ collection tube. Centrifuge at $6000 \times \mathrm{g}(8000 \mathrm{rpm})$ for $1 \mathrm{~min}$. (Discard flow through).

2.4.9. Repeat Step 12 with the remaining portion of the mixture. Discard flow-through and collection tube.

2.4.10. Place the spin column in a new $2 \mathrm{ml}$ collection tube. Add $500 \mu \mathrm{l}$ of Buffer AW to the column and centrifuge at $8000 \mathrm{rpm}$ for $1 \mathrm{~min}$. Discard flow-through.

2.4.11. Add another $500 \mathrm{ml}$ of AW and centrifuge for $2 \mathrm{~min}$ at $20,000 \mathrm{x} \mathrm{g}$ $(14,000 \mathrm{rpm})$ to dry the membrane.

2.4.12. Transfer the spin column to a $1.5 \mathrm{ml}$ microcentrifuge tube and pipet $200 \mu \mathrm{l}$ of Buffer AE (room temperature) onto the column membrane. Incubate for $5 \mathrm{~min}$ at room temperature and then centrifuge for $1 \mathrm{~min}$ at $6,000 \mathrm{xg}(8000 \mathrm{rpm})$ to collect DNA elution (do not allow the column to dry).

2.4.13. Extracts of total genomic DNA can be stored at $4^{\circ} \mathrm{C}$ for immediate use or at $-20^{\circ} \mathrm{C}$ for use in the future.

\subsection{Real-time PCR (method according to Harper et al., 2010)}

Harper et al. (2010) developed Real-time PCR assays targeted to the rimM gene of $X$. fastidiosa, which detected all bacterial subspecies. The primer set has been previously tested and proved to be suitable for detection of CoDiRo strain in olive tissues (Table 1). The composition of reaction mix and thermal cycling conditions are given in Tables 2 and 3. Each reaction should include the positive, the negative and the non-template controls. For this method, samples should be run in duplicate wells. Presence of DNA band of expected size means 


\begin{tabular}{|l|l|}
\hline \multicolumn{1}{|c|}{ Primer or probe } & \multicolumn{1}{c|}{ Sequence (5'-3') } \\
\hline XF-F (forward) & CACGGCTGGTAACGGAAG \\
\hline XF-R (reverse) & GGGTTGCGTGGTGAAATCAAG \\
\hline XF-P (probe) & 6FAM-TCGCATCCCGTGGCTCAGTCC-BHQ1 \\
\hline
\end{tabular}

Table 1: Primers and probes for quantitative real-time PCR.

\begin{tabular}{|l|l|}
\hline \multicolumn{1}{|c|}{ Reagent } & \multicolumn{1}{c|}{ Volume } \\
\hline Total genomic DNA & $1 \mu \mathrm{l}$ \\
\hline $2 \times$ master mix for probes & $5.5 \mu \mathrm{l}$ \\
\hline $10 \mu \mathrm{M}$ Forward Primer & $0.3 \mu \mathrm{l}$ \\
\hline $10 \mu \mathrm{M}$ Reverse Primer & $0.3 \mu \mathrm{l}$ \\
\hline $10 \mu \mathrm{M}$ TaqMan Probe & $0.1 \mu \mathrm{l}$ \\
\hline Molecular grade water & $3.8 \mu \mathrm{l}$ \\
\hline Total & $\mathbf{1 1} \boldsymbol{\mathbf { l }}$ \\
\hline
\end{tabular}

Table 2: Reaction mix for quantitative real-time PCR.

\begin{tabular}{|l|l|}
\hline $50^{\circ} \mathrm{C} 2 \mathrm{~min}$ & 1 cycle \\
\hline $95^{\circ} \mathrm{C} 10 \mathrm{~min}$ & 1 cycle \\
\hline $94^{\circ} \mathrm{C} 10 \mathrm{sec}$ & 39 cycles \\
\hline $62^{\circ} \mathrm{C} 40 \mathrm{sec}$ & \\
\hline
\end{tabular}

Table 3: Real-time PCR conditions.

that sample is positive. If a sample produces a FAM Cq value in the range of $0.00<$ FAM Cq $<35.00$, the sample is determined to be positive for $X$. fastidiosa and if produces a FAM Cq=0.00 or $>35.0$, then it is determined to be negative. If the FAM Cq value is between 32.01 and 34.99 , then the samples have to be tested again in real-time PCR to confirm the result.

\section{Acknowledgements}

This work was funded by EU Commission project AREA, no. 316004. I would like to thank National Research Council (CNR) and Institute for Sustainable Plant Protection (IPSP) in Bari, especially Dr Maria Saponari who was excellent 
supervisor. All detection protocols are published by CNR Instituto per la Protezione Sosteinibile delle Piante (Bari, Italy), in the framework of workshop "Current tools for the detection of Xylella fastidiosa in host plants and vectors" (Saponari et al. 2014).

\section{References}

Cariddi, C., Saponari, M., Boscia,D., Stradis, A. D., Loconsole, G., Nigro, F., Porcelli, F., Potere, O., \& Martelli, G. P. (2014). Isolation of a Xylella fastidiosa strain infecting olive and oleander in Apulia, Italy. Journal of Plant Pathology, 96(3), 1-5. DOI: https://doi.org/10.4454/JPP.V96I2.024

EPPO (2016). First report of Xylella fastidiosa in EPPO region, Special Alert. Retrieved from http://www.eppo.int/QUARANTINE/special_topics/ Xylella_fastidiosa/Xylella_fastidiosa.htm

Harper, S. J., Ward, L. I., \& Clover, G. R. G. (2010). Development of LAMP and Real-Time PCR Methods for the Rapid Detection of Xylella fastidiosa for Quarantine and Field Applications. Phytopathology, 100(12), 1282-1288, DOI: https://doi.org/10.1094/PHYTO-06-10-0168

Saponari, M., Loconsole, G., Potere,O., Palmisano, F., \& Boscia, D. (2014). Current protocols for detection of Xylella fastidiosa in host plants and vectors. Workshop manual, CNR Instituto per la Protezione Sosteinibile delle Piante, Bari, Italy. Retrieved from ftp://ftpfiler.to.cnr.it:21001/Xylella_symposium/Workshop\%20manuals/WORKSHOP\%20MANUAL\%20DETECTION\%20ENG.pdf 
